\title{
Mihin ergonomia on kadonnut työpaikkojen kehittämisessä?
}

\author{
Arto Reiman \& Teemu Suokko
}

Kohtaamme työssämme päivittäin tilanteita, joissa paremmin suunniteltu ja johdettu vuorovaikutusyhteys ihmisen, organisaation ja teknologian välillä mahdollistaisi toiminnan tehostamisen sekä työhyvinvoinnin lisäämisen. Tyypillisinä esimerkkeinä tästä voidaan nostaa esille työpistejärjestelyjen muokkaaminen vastaamaan työn vaatimuksia. Ergonomiakirjallisuudessa tällaista yksittäisiin työpisteisiin kohdentuvaa kehittämistoimintaa kutsutaan mikroergonomiaksi (esim. Kleiner 2008). Suomalainen ergonomia-asiantuntemus keskittyy varsin laajasti juuri mikroergonomisiin osakokonaisuuksiin. Toisaalta ergonomiaymmärryksemme tuntuu kokemustemme mukaan olevan huomattavasti puutteellisempaa laajemmassa työelämäkontekstissa, eikä suomalainen ergonomiaosaaminen kykene riittävällä tavalla käsittämään ja käsittelemään yksittäisistä työpisteistä muodostavia kokonaisuuksia, eli esimerkiksi kokonaisia tuotantoympäristöjä. Kansainvälisessä ergonomiakirjallisuudessa tällaista laajempaa, organisatorista ymmärrystä edellyttävää ergonomiatoimintaa kutsutaan makroergonomiaksi (emt.).

Suomessa kehitys työterveydessä, -turvallisuudessa ja -hyvinvoinnissa on ollut huimaa pidemmällä aikavälillä tarkasteltuna. Kehitys tuntuu kuitenkin jääneen paikalleen, kun tarkastellaan esimerkiksi tapaturma- ja työperäisten sairauksien kehitystä Suomessa 2000-luvulla (Kela 2019; Tapaturmavakuutuskeskus 2020a.). Näiden on osoitettu aiheuttavan val- tavia haittakustannuksia suomalaiselle yhteiskunnalle, työpaikoille sekä yksilöille (Rissanen \& Kaseva 2014; European Agency for Safety and Health at Work 2019). Toisaalta näkymä kuitenkin on, ettei haittakustannusten taloudellista merkitystä sekä niiden vähentämiseen liittyvää taloudellista potentiaalia ymmärretä edelleenkään riittävästi työpaikkatasolla. Ergonomia suunnittelutieteellisenä oppialana tarjoaa sekä viitekehyksen että konkreettisia työkaluja työpaikkojen kehittämiseen niin työhyvinvoinnin kuin tuottavuuden näkökulmasta (Karwowski 2005; Dul ym. 2012). Ergonomian työkalujen avulla voidaan tunnistaa yksilötason haittakuormitustekijöitä sekä suunnitella monipuolisesti niiden hallintakeinoja. On huomioitava, ettei ergonomia kategorisesti pyri tunnistamaan vain tietynlaisia kuormitustekijöitä, vaan sen lähtökohtana on kuormitustekijöiden kokonaisvaltainen tunnistaminen työhyvinvoinnin ja tuottavuuden kehittämisen mahdollistamiseksi (Karwowski 2005; Dul ym. 2012).

Työturvallisuuden, -terveyden ja -hyvinvoinnin kehittämistarpeet on tunnistettu varsin näkyvästi esimerkiksi Suomen puheenjohtajakaudella Euroopan Unionin uusissa linjauksissa liittyen hyvinvointitalouteen (Euroopan unionin neuvosto 2019a) ja työterveyden ja -turvallisuuden uusiin linjauksiin (Euroopan unionin neuvosto 2019b). Nämä kehittämistarpeet on tunnistettu myös sekä Suomen hallitusohjelmassa (2019) että Sosiaali- ja 
terveysministeriön (2019) työhyvinvoinnin ja työympäristön linjauksissa. Kuitenkin vaikuttaisi siltä, ettei ole yhteistä näkymää siitä, miten nämä linjaukset konkreettisesti siirtyisivät käytäntöön suomalaisilla työpaikoilla. Onko tämä seurausta johtamisen puutteista tai kenties konkreettisten kehittämismenetelmien tai riittävän asiantuntemuksen puutteista työpaikoilla? Voidaan myös kysyä, kenen rooliin työpaikoilla lopulta kuuluu työhyvinvoinnin ja tuottavuuden kehittäminen. Tutkimukset (esim. Dul \& Neumann 2009) ovat osoittaneet, että henkilöstöhallinnon ja työturvallisuusorganisaation roolit ovat usein varsin siiloutuneet eivätkä useinkaan suoraan kytköksissä päätöksiä tekevään ylimpään johtoon. Työterveyshuollolla on myös oma roolinsa työhyvinvoinnin kehittämisessä joko ulkopuolisena palvelun tarjoajana tai organisaation osana. Suomalaisissa tutkimuksissa (esim. Ahonen ym. 2011) on korostettu strategisen työterveyshuoltokumppanuuden merkitystä. Toisaalta voidaan myös kysyä, millaisia tosiasiallisia mahdollisuuksia ja työkaluja työterveyshuollollakaan on työpaikkakohtaiseen ja työpaikoilla tapahtuvaan työhyvinvoinnin ja tuottavuuden kehittämiseen.

Kenen rooliin tällainen synergistinen työhyvinvoinnin ja tuottavuuden kehittäminen sitten voisi kuulua työpaikoilla? Ilmeinen vastaus on, että tämä olisi kaikkien toimijaryhmien intresseissä, mutta kuten edellä toimme esille, näyttää tässä kehittämistyössä edelleen olevan runsaasti haasteita. Ergonomia yli 150 vuotta vanhana suunnittelutieteellisenä ja ihmiskeskeisenä tieteenalana tarjoaa tähän haasteeseen oman ratkaisukeskeisen näkökulmansa (Karwowski 2005). Ergonomia on tieteenala, joka auttaa ymmärtämään ihmistä eri ympäristöissä sekä työssä että työajan ulkopuolella. Ergonomian asiantuntijat kykenevät monin tavoin edistämään työn, työympäristöjen, -menetelmien ja -välineiden, tuotteiden, organisaatioiden sekä toimintajärjestelmien suunnittelua, arviointia ja johtamista huomioiden ihmisten tarpeet, kyvyt sekä rajoitukset. Tällaisessa ihmiskeskeisessä kehit- tämisessä tarvitaan monipuolista ergonomiatietoa sekä -osaamista ja yhteistyötä eri toimijoiden välillä. Ergonomian asiantuntijoiden tehtävänä onkin edistää tätä vuorovaikutusta sekä tuoda omaa asiantuntemustaan mukaan suunnittelu- ja johtamisprosesseihin (Launis \& Lehtelä 2011).

\section{Ergonomia tarjoaa työkaluja työn ymmärtämiseen ja kehittämiseen}

Kansainvälisesti hyväksytyn määritelmän mukaisesti "ergonomia tarkastelee tieteenalana ihmisen ja toimintajärjestelmän muiden osien vuorovaikutuksia ja soveltaa ammattialana ergonomian teoreettisia periaatteita, tietoja ja menetelmiä ihmisen hyvinvoinnin ja toimintajärjestelmän tehokkuuden optimoimiseksi" (Karwowski 2005; Launis \& Lehtelä 2011; Dul ym. 2012). Käsite toimintajärjestelmä on tässä tarkastelussa moniulotteinen. Toimintajärjestelmää voidaan lähestyä mikroergonomisesti keskittyen yhden yksilön omaan työjärjestelmään. Toisaalta toimintajärjestelmää voidaan tutkia myös makroergonomisesti esimerkiksi työyhteisön, organisaation tai organisaatioverkostojen näkökulmista (Dul ym. 2012) laajentaen tarkastelua aina vaikuttamiseen globaaleissa kestävän kehittämisen haasteissa (Thatcher ym. 2018). Yksinkertaisimmillaan ergonomia tutkii yksittäistä työntekijää työpisteessään. Tämän varsin tyypillisen tarkastelunäkökulman vaarana on tarkastelun rajoittuneisuus, jolloin ei kyetä ymmärtämään useista työntekijöistä muodostuvia kokonaisuuksia. Tällainen lähestymistapa voi johtaa osaoptimointiin laajemman järjestelmän muiden osien kustannuksella (Dul ym. 2012).

Ergonomia luonnostaan monitieteisenä oppialana tarjoaa työkaluja sekä mikroergonomisten että laajempien makroergonomisten kokonaisuuksien ymmärtämiseen ja kehittämiseen. Tämän kokonaisuuden hallinta sekä kehittäminen edellyttävät eri toimija- ja sidosryhmien huomioimista. Ergonomialle keskeistä onkin osallistuminen sekä osallistuva suunnittelu. Yrityksen sisällä osallistuminen voi to- 
teutua monin tavoin, mutta usein se tarkoittaa kaikkien olennaisten henkilöstöryhmien sekä johdon osallistumista ja sitoutumista (Vink ym. 2008; Burgess-Limerick 2018). Onnistunut ergonomiakehitysprosessi edellyttää myös ergonomia-asiantuntijan osallistumista. Ergonomia-asiantuntija voi tulla sekä yrityksen sisältä että ulkopuolelta (Haims \& Carayon 1998). Osallistuminen, systemaattinen ja pitkäjänteinen kehittämisote sekä kyky uudenoppimiseen ovat keskeisiä elementtejä onnistuneelle ergonomiakehittämiselle (Carayon 2006). Ergonomiakehittämisen vaikuttavuutta on tuotu esille esimerkiksi Driessenin ym. (2010) sekä Westgaardin ja Winkelin (2011) katsausartikkeleissa. Toisaalta on tuotu myös esille vaikuttavuustutkimuksen haasteita nostaen erityisesti esille satunnaistettujen kontrolloitujen kokeiden järjestämisen haasteellisuus ja yleisesti kustannus-hyötylaskennan tulosten vertailun vaikeus maakohtaisten eroavaisuuksien vuoksi (Dempsey 2007; Driessen ym. 2010).

\section{Mitä systemaattisella ergonomia- kehittämisellä voi saavuttaa?}

Kuten kansainvälinen ergonomiakirjallisuus osoittaa, ergonomian oppien avulla tapahtuvalla työnteon edellytysten, eli työyhteisön, -ympäristön, -tehtävien ja -kalujen kehittämistyöllä voidaan vaikuttaa sekä työhyvinvointiin että mahdollistaa tehokkaampi ja tuottavampi työnteko. Konkretisoidaksemme tätä kuvaamme tässä puheenvuorossa systemaattisen, ergonomiaoppien mukaisen muutosprosessin lähtötilanteesta nykytilaan eräässä valmistavan teollisuuden pk-yrityksessä Suomessa. Kehitysprosessin keskeisenä tavoitteena oli sujuvoittaa tuotantoprosessia, mutta myös parantaa työhyvinvointia henkilöstöön kohdistuvia haittakuormitustekijöitä vähentämällä. Kehitysprosessia kuvaavina tuottavuuden tunnuslukuina käytämme tuotteiden valmistuskapasiteettia ennen ja jälkeen muutoksen. Työhyvinvointia kuvaavina tunnuslukuina käytämme tapatur- mataajuuden (sattuneet työtapaturmat miljoonaa työntuntia kohden), sairauspoissaolojen ja korvaavan työn määrän muutosta vuositasolla. Työhyvinvoinnin kokemusta kuvaavina mittareina käytämme Happy or not -mittauksia. Happy or not -mittauksissa henkilöstöllä oli mahdollisuus päivittäin ottaa kantaa sosiaalitilojen ulkopuolella sijoitetulla päätteellä sen hetkiseen työhyvinvointituntemukseensa neliportaisella asteikolla "erittäin negatiivisesta" "erittäin positiiviseen". Lisäksi hyödynnämme kehitysprosessia edeltävien henkilöstön, työsuojelupäällikön ja tuotantopäällikön välisten haastatteluiden muistiinpanoja sekä materiaalia kehitysprosessin alussa henkilöstölle suoritetuista työpistekohtaisista kuormitusmittauksista.

Kohdeyrityksemme on osa laajempaa suomalaisomisteista konsernia, toimien kuitenkin omana tuotantoyksikkönään. Tuotantoyksikössä valmistetaan perävaunuja sekä venetrailereita. Tuotantoyksikössä oli kehittämisprosessin käynnistyessä yhteensä neljätoista työntekijää sekä neljä toimihenkilöä. Työntekijöiden työ oli pääasiassa käsin tehtävää kokoonpanotyötä. Tuotantotiloissa toimi myös maalaamo, jossa tehtiin osien pintakäsittelyä. Valmistus tapahtui osavalmistukseen tarkoitetuilla levytyöstökoneella, levyleikkurilla sekä kahdella särmäyskoneella. Lisäksi tuotantotiloissa toimi proto-osasto, jossa tehtiin tuotteiden ja tuotantovälineiden kehitystä. Kokoonpanotyö oli jaettu osakokoonpanoon sekä perävaunukokoonpanoon. Työntekijät olivat statukseltaan osakokoonpanijoita ja perävaunukokoonpanijoita.

Osakokoonpanotyötä suoritettiin kolmena erilaisena työvaiheena. Koottavat osat olivat trukkilavoilla, joko kuormahyllyissä tai lattialla. Osat siirrettiin käsin trukkilavoilta osakokoonpanomuottiin, jossa ne liitettiin yhteen käsityökaluilla. Osakokoonpanon työpisteiltä valmiit tuotteet siirrettiin käsin valmiiden tuotteiden telineisiin. Ne olivat käsin liikuteltavia ja siirrettävissä tarpeen mukaan työpisteisiin tai välivarastoon. Perävaunukoonpanon työ oli mahdollista suorittaa yksin tai pareittain. Valmistukseen tarvittavat osat olivat 
trukkilavoilla tai laatikoissa kuormahyllyillä, telineissä tai lattialla. Osat tuotiin trukilla kokoonpanopisteisiin, josta ne siirrettiin käsin kokoonpanon muotteihin. Perävaunut koottiin käsityökaluilla. Valmiit tuotteet siirrettiin nosturilla käytävälle odottamaan siirtoa ulos varastoitavaksi. Sekä kokoonpanoon että perävaunukokoon liittyen valmistettavan mallin vaihtuessa koottavia osia oli vaihdettava ja järjesteltävä työpisteissä. Tämä edellytti käsin tehtäviä työvaiheita.

Käytettävissä oleva tila tuotti haasteita työn sujuvuuden ja häiriöttömyyden hallinnassa. Haasteena sujuvan työn suorittamiseksi oli, että työaikaa käytettiin paljon tuottamattomaan työskentelyyn kuten tavaroiden siirtelyyn. Kokoonpanon käytävä tukkeutui valmiista tuotteista sekä kokoamista odottavista osista ja aiheutti logistisia häiriöitä. Työpisteiden uudelleenjärjestely tuotti henkilöstölle ylimääräistä käsin tehtävää työtä tuotemallien vaihtuessa. Lisäksi haastatteluiden perusteella henkilöstö koki voimakkaasti, ettei työn tekeminen ollut järkevää, sujuvaa ja häiriötöntä. Tämän vuoksi tuotantoyksikössä käynnistettiin muutosprosessi, jolle asetettiin tavoitteiksi työhyvinvoinnin parantaminen, tuottavuuden edistäminen, epäsuoran työn vähentäminen sekä materiaalivirtojen selkeyttäminen.

Varsinainen muutosprosessi käynnistettiin vuoden 2018 jälkimmäisellä puoliskolla. Muutosprosessi sekä henkilöstön osallistaminen vastuutettiin tuotantopäällikölle. Työsuojelupäällikkö (TS, toinen kirjoittajista) toimi ergonomia-asiantuntijana muutosprosessissa koko organisaation tukena toimivan keskusteluyhteyden synnyttämiseksi sekä ylläpitämiseksi. Osallistumisen systemoimiseksi otettiin käytännöksi viikkopalaveri, joissa muutoksen vaiheita ja käytännön toteutusta käytiin henkilöstön kanssa avoimesti läpi. Muutosten tukena hyödynnettiin myös 3Dmallinnusohjelmaa, joka mahdollisti työympäristömuutosten visuaalisen tarkastelun jo suunnitteluvaiheessa.

Tuotantoprosessin muutos toteutettiin loppusyksyn 2018 ja alkukevään 2019 välisenä aikana. Tuotantotilojen uudelleenjärjestelyjen mahdollistamiseksi osavalmistuskoneet siirrettiin pois tehtaalta. Osakokoonpanon työpisteet siirrettiin ja järjesteltiin alueille, joissa työn suorittamiseen oli riittävästi tilaa. Perävaunukokoonpano muutettiin linjamalliseksi, jolloin osia voitiin tuoda kuormahyllyihin siten, ettei kokoonpanotyö keskeydy. Valmiiden tuotteiden osalta mahdollistettiin siirto nostimilla pois työpisteeltä käytävälle muun logistiikan häiriintymättä. Työpisteiden muutosten ohella henkilöstön työaikoja yhdenmukaistettiin. Tuotanto suunniteltiin ja sovittiin alkamaan ja loppumaan osa- ja perävaunukokoonpanotyöpisteillä samaan aikaan. Lisäksi kehitettiin tuotannonohjausta toiminnanohjausjärjestelmässä vastaamaan tuotannon vaatimuksia sekä parannettiin tuotantotilojen sisäistä logistiikkaa tukemaan keskeytyksetöntä työntekoa. Olemme visualisoineet tätä työympäristössä tapahtunutta muutosta kuvissa $1 \mathrm{a}$ ja $1 \mathrm{~b}$.

Edellä kuvattua muutosprosessia voidaan tarkastella investointina, jonka keskeisimpiä kustannuselementtejä olivat kehittämiseen käytetty työaika sekä materiaali- ja tarvikekustannukset. Työajan osalta kustannuksia kertyi 24300 euroa tunti- ja palkkakirjanpidon perusteella laskien. Materiaalien ja tarvikkeiden osalta kustannuksia syntyi maalaus- ja varastotarvikkeista, sähkötöistä, paineilmasta, laitevuokrista sekä uusista led-valaisimista. Kokonaisuutena materiaali- ja tarvikekustannuksia kertyi 26400 euroa. Henkilöstö toteutti itse käytännön muutokset tehtaalla sähkötöitä lukuun ottamatta. Yhteensä muutosprosessi maksoi yritykselle investointina 50700 euroa.

Ennen muutosprosessin käynnistymistä henkilöstölle suoritetuilla kuormitusmittauksilla selvitettiin suuntaa-antavasti haitallisten työasentojen osuutta työpäivän aikana kaikissa kokoonpanon työvaiheissa. Kuormitusmittaus koostui työsuojelupäällikön työpäivän aikana suorittamista videokuvauksista sekä videomateriaalin jälkikäteisestä analysoinnista. Analyysiin osallistuivat työsuojelupäällikkö sekä työterveyshuoltoa edustanut työfysio- 

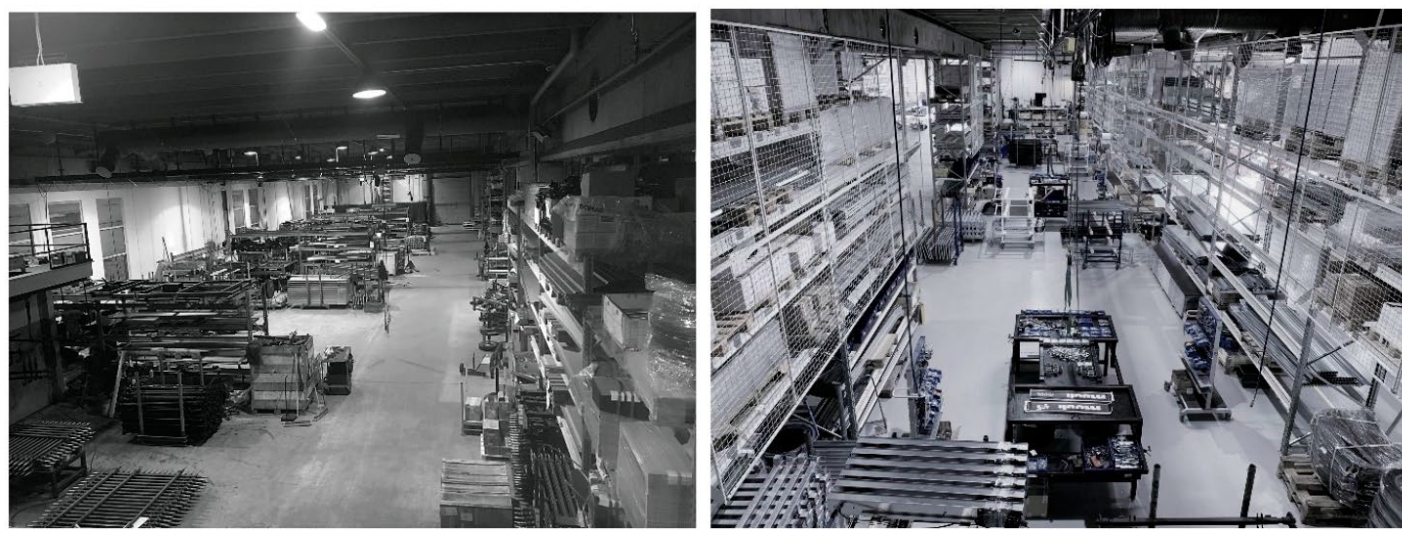

Kuva 1a. Esimerkkikuva perävaunukokoonpanosta ennen muutosprosessia sekä b) muutosprosessin jälkeen (Kuvaaja: Henri Saarimaa).

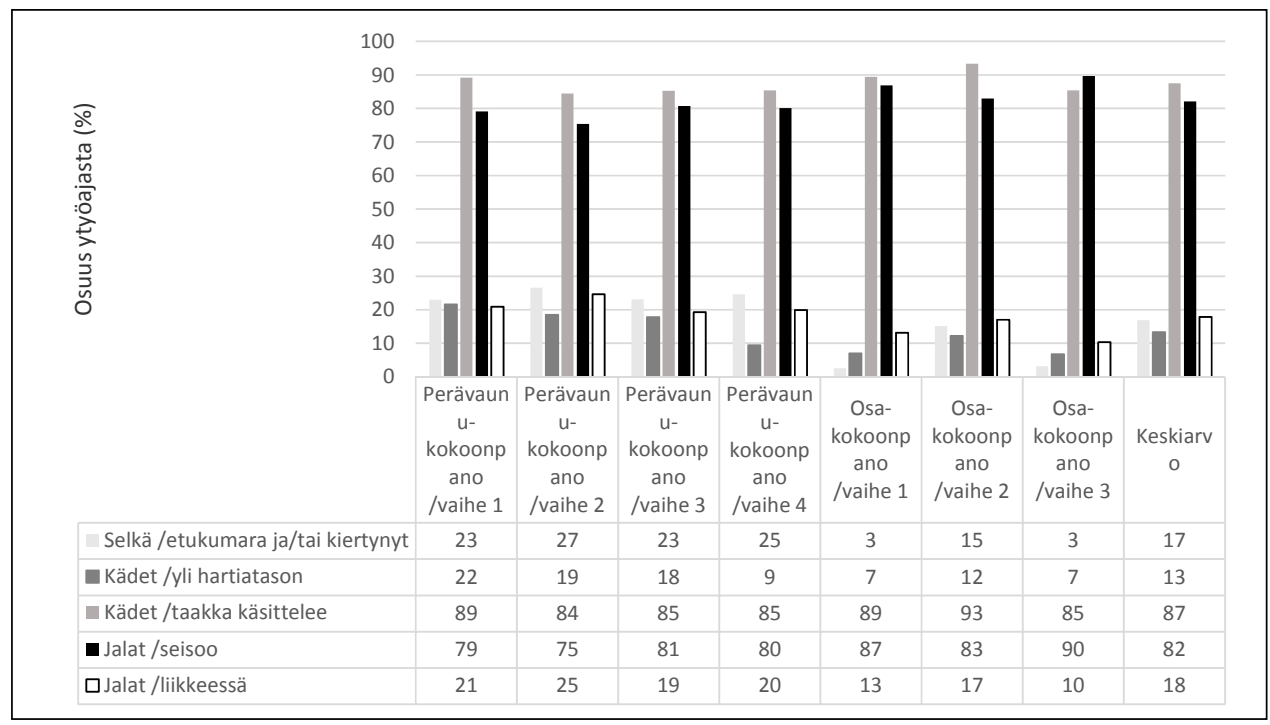

Kuvio 1. Työn kuormitusmittausten tulokset muutosprosessin alussa.

terapeutti. Analyysissa haitallisten työasentojen osuus mitattiin sekuntikellolla videomateriaalista. Kuormitusmittausten tuloksia on esitelty kuviossa 1. Kuormitusmittauksiin sekä videokuvauksiin pyydettiin lupa henkilökohtaisesti jokaiselta kohteena olleelta työntekijältä ja kerättyä aineistoa hyödynnettiin vain analyysissa.

Kuviossa 1 esiteltyjen kuormitusmittausten perusteella voidaan todeta työn fyysisen kuormittavuuden vaihdelleen työvaiheittain. Perävaunukokoonpanon vaiheet sisälsivät selkeästi osakokoonpanon vaiheita enemmän etukumarassa tai kiertyneissä asennoissa suoritettua työskentelyä. Lisäksi työvaiheisiin sisältyi enemmän työskentelyä, jossa kädet olivat hartiatason yläpuolella. Osakokoonpanotyössä toisaalta oltiin keskimäärin hieman enemmän seisovassa asennossa. Kuormitusmittausten perusteella päätettiin osana muutosprosessia toteuttaa työkierto osakokoonpanon ja perävaunukokoonpanon välillä henkilöstön työn kuormituksen tasaamiseksi. 


\section{Mitä muutosprosessilla saavutettiin?}

Muutosprosessin tavoitteena oli parantaa työhyvinvointia sekä edistää tuottavuutta parantamalla tuotantokykyä, vähentämällä ei-tuottavia työsuorituksia sekä selkeyttämällä materiaalivirtoja. Keskeisimpänä edellä mainittua tuotantoprosessin kehittymistä kuvaavana tuottavuuden mittarina seurattiin tuotantokapasiteetin määrää ennen ja jälkeen muutosprosessin. Muutosprosessi mahdollisti materiaalivirtojen sujuvoittamisen ja tuottamattoman työn vähentämisen sekä tästä seuranneiden työmääräresurssien siirtämisen tuottavaan työhön. Muutosten myötä tehtaan kokonaistuottavuus nousi viisi prosenttia. Vuositasolla tämä tarkoittaa valmistuskapasiteetin nousua 250 tuotteella henkilöstömäärän pysyessä samana.

Muutosprosessi näyttää johtaneen myös selkeisiin parannuksiin sekä kustannussäästöihin sairauspoissaolopäivien määrän vähentymisen myötä. Sairauspoissaolopäiväkehitykseen vaikuttivat myös työterveyshuollon parantuneet mahdollisuudet kohdistaa osatyökykyisille sopivaa työtä työkyvyn rajoitteet huomioiden, koska työvaiheittainen kuormitus oli tarkemmin tiedossa kuormitusmittausten myötä. Vuonna 2018 tuotantoyksikköön koh- distui 399 sairauspoissaolopäivää, kun vuonna 2019 sairauspoissaolopäiviä kertyi 130 . Lisäksi vuonna 2019 tehtiin yhteensä 34 korvaavan työn päivää. Sairauspoissaolojen vähennyksestä vuoden 2019 osalta verrattuna vuoden 2018 kustannustasoon kertyi kustannussäästöä yhteensä 94150 euroa sekä 11900 euroa lisääntyneen korvaavan työn myötä. Kokonaisuudessaan sairauspoissaoloihin liittyvät kustannussäästöt olivat näin 106050 euroa verrattaessa vuoden 2018 tilanteeseen. Muutosprosessi näkyi myös työturvallisuuden tason selkeänä parantumisena vuoden 2019 jälkimmäisen puoliskon aikana. Työtapaturmien liukuva taajuus putosi vuoden jälkimmäisellä puoliskolla nollaan, sen ollessa aiemmin reilusti yli teollisuuden keskiarvon $(30,9)$ kun vertailulukuna käytetään Tapaturmavakuutuskeskuksen (2020a) tuottamia tilastoja.

Muutosprosessilla näyttää olleen vaikutusta myös henkilöstön kokemaan työhyvinvointiin. Tätä seurattiin Happy or not -mittauksilla kuukausittain. Kuukausittain kertyi keskimäärin 78 vastausta. Vastauksista voidaan havaita selvästi muutos positiivisemman työhyvinvoinnin suuntaan vuoden 2019 aikana (kuvio 2) kun muutosprosessi oli saatettu valmiiksi.

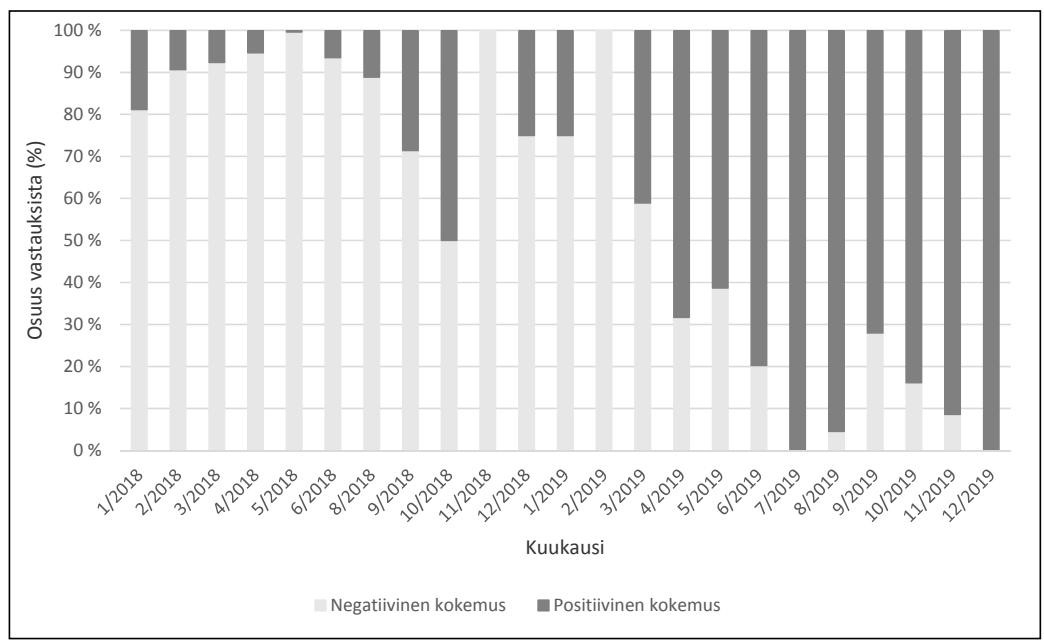

Kuvio 2. Henkilöstön työhyvinvointia kuvaavien happy or not -kuukausimittausten vastausjakauma. Kuviossa negatiivinen kokemus kuvaa vaihtoehtoja "erittäin negatiivinen" ja "negatiivinen" sekä positiivinen kokemus vaihtoehtoja "erittäin positiivinen" ja "positiivinen". 


\section{Pohdinta vaikutuksista ja vaikuttavuudesta}

Tässä puheenvuorossa esitetty kuvaus ergonomian oppien mukaan toteutusta muutosprosessista osoittaa, millaisia vaikutuksia systemaattisella ja osallistavalla ergonomiakehittämisellä on ollut tuotantoyksikön tuottavuuteen ja työhyvinvointiin. Vaikutukset ovat todennettavissa sekä euromääräisesti että valitsemillamme mittareilla, joilla olemme pyrkineet kuvaamaan työhyvinvoinnin muutosta. Huomioitava on, että kuvatut kustannusvaikutukset sekä muutokset henkilöstön hyvinvoinnissa ovat varsin nopealla aikataululla saavutettuja sekä tuntuvia ottaen huomioon tuotantoyksikön pienen koon.

Muutosprosessin vaikutuksia on kuitenkin syytä tarkastella myös kriittisemmin ergonomian tutkimusperinteiden näkökulmasta. On huomioitava, että kuvattu tarkastelujakso on erittäin lyhyt rajoittuen vuosiin 2018 ja 2019. Henkilöstön kokema työhyvinvointi näyttää kehittyneen selvästi muutosprosessin myötä. Mahdollisesti työhyvinvoinnin tason selkeä kohoaminen Happy or not -tarkastelussa selittyy osin uuden viehätyksellä. Näin on mahdollista, että työhyvinvoinnin kokemukset jäävät lyhytaikaisiksi. Saattaa myös olla, että positiiviselta näyttävä kehitys on osa pidempikantoista muutosta yrityksessä tai seurausta muista, osin myös satunnaisista syistä. Tämän vuoksi esimerkiksi sairauspoissaolojen ja työtapaturmien määrät voivat palata aiemmalle tasolleen tulevina vuosina.

Tapaturmavakuutuskeskuksen (2020a) tilastojen mukaan suomalaisen teollisuuden työtapaturmien keskeiset tunnusluvut ovat viimeisen kymmenen vuoden tarkasteluvälillä pysyneet varsin vakaina. Esimerkiksi työtapaturmataajuus on pysynyt yli kolmessakymmenessä koko tarkasteluajanjakson, eli viimeisten kymmenen vuoden aikana. Työtapaturmien tarkempi tarkastelu Tapaturmavakuutuskeskuksen (2020b) Pakki-tilastosovelluksen avulla nostaa esille, että yhdeksän kymmenestä teollisuuden työtapaturmasta (yhteensä 16277) vuonna 2018 liittyi esineiden käsittelemiseen, taakan käsivoimin siir- tämiseen, käsikäyttöisillä työkaluilla työskentelyyn, koneiden käyttöön sekä liikkumiseen. Tämän puheenvuoron myötä näyttää ilmeiseltä, että ergonomialla suunnittelukeskeisenä oppialana ihmisen, organisaation ja teknologian vuorovaikutuksen kehittämiseen olisi paljon tarjottavaa tämänkaltaisten ihmisen toimintaa sisältävien ja ihmistä kuormittavien haasteiden ratkaisemiseksi.

Edellä esille tuotujen näkökulmien vuoksi toteamme, ettei vielä tässä vaiheessa ole mahdollista tieteellisesti luotettavasti arvioida kuvatun muutosprosessin vaikuttavuutta. Toisaalta on kuitenkin perusteltua todeta, että kuvatulla ergonomiaoppien mukaisesti toteutetulla muutosprosessilla näyttää olleen selviä vaikutuksia sekä työhyvinvointiin että tuottavuuteen. Muutosprosessi näyttää maksaneen itsensä investointina takaisin varsin nopeasti jo pelkästään vähentyneinä sairauspoissaoloja tapaturmamäärinä sekä niihin liittyvinä kustannuksina. Lisäksi tuotantokapasiteetin nousu antaa viitteitä muutosprosessin onnistumisesta tuottavuuden näkökulmasta.

Keskeisenä oppina nostamme esille seuraavia huomioita. Ensinnäkin osallistava, yhdessä toteutettu muutosprosessi tarjosi työntekijöille konkreettisesti mahdollisuuden vaikuttamiseen. Toiseksi turhan ja epäoleellisen sekä tuottamattoman työn vähentyessä työn mielekkyys näyttää lisääntyneen. Tämä puolestaan vaikuttaa positiivisesti työhyvinvointiin. Työn sujuvuutta ja häiriöttömyyttä edisti myös samanaikaisesti tapahtunut tuotannonohjausjärjestelmän kehittäminen. Tuotannonohjausjärjestelmän kehittämisen myötä työn suunnittelu muuttui loogiseksi ja ennustettavammaksi, jolloin myös työn ja työprosessien suunnittelu muuttui helpommin hallittavaksi. Kolmantena oppina nostamme esille ergonomia-asiantuntijan merkityksen muutosprosessin tukena. Ergonomia-asiantuntija pystyi oman työsuojelupäällikkötehtävänsä myötä osallistumaan muutosprosessiin koko sen keston ajan mahdollistaen näin ergonomia-asiantuntemuksen kaikissa muutosprosessin vaiheissa. 
On syytä myös muistuttaa, etteivät esimerkiksi tuotantoteknologioiden kehittyminen tai lisääntyvä digitalisaatio tai robotisaatio tule todennäköisesti ainakaan lähivuosina tarjoamaan ratkaisuja edellä kuvatun kaltaisiin työpaikkatason haasteisiin. Kuten Badri ja kumppanit (2018) sekä Alasoini (2019) tuovat katsausartikkeleissaan esille, teknologia ei tule todennäköisesti täysin korvaamaan ihmistä tuotantoprosesseissa myöskään tulevaisuudessa, vaan ihminen tulee säilymään osana tuotantoprosesseja. Teknologian kehittymisen myötä ihmisen rooli todennäköisesti kuitenkin muuttuu puheenvuorossamme kuvatun kaltaisilla työpaikoilla enemmän operaattorimaisiksi tehtäviksi. Näissä tehtävissä kognitiivinen kuormitus tulee todennäköisesti korostumaan fyysisten kuormitustekijöiden ohella. Näkemyksemme mukaan tällaisten valmistavan teollisuuden työympäristöjen ja prosessien optimoiminen edellyttääkin tulevaisuudessa entistä syvällisempää sosioteknistä ymmärrystä yrityksen ja henkilöstön valmiuksista sekä kyvykkyydestä uusien teknologioiden hyödyntämiseen. Myös tällaisten haasteiden osalta on hyvä huomioida ergonomian ja ergonomien tarjoamat työkalut niin fyysisiin, kognitiivisiin kuin organisatorisiinkin haasteisiin.

\section{Lopuksi}

Ergonomia on lähtökohdiltaan suunnittelutieteellinen oppiala, joka pyrkii kehittämään ihmisen ja järjestelmien vuorovaikutusta tehokkaammaksi ja turvallisemmaksi. Työhyvinvoinnin ja tuottavuuden kehittäminen on tunnistettu yhdeksi keskeisimmistä kilpailukykyyn liittyvistä haasteista niin valtakunnallisesti kuin Euroopankin tasolla. Työelämän ja teknologioiden kehittyminen tekee tästä synergisestä kehittämisestä entistäkin monimutkaisempaa. Keskeinen kysymys on, millaista on suomalaisten työpaikkojen kyvykkyys muutoksen johtamiseen työhyvinvoinnin ja tuottavuuden yhtäaikaisen kehittämisen näkökulmasta? Lisäksi on syytä kysyä mikä on se taho yrityksessä, joka luontevimmin pystyisi fasilitoimaan tällaista kehittämisprosessia? Tässä puheenvuorossa olisi luontevaa todeta, että tällaisessa työhyvinvoinnin ja tuottavuuden yhteiskehittämisprosessissa parhaimpana asiantuntijana toimisi johdon valtuuttama ergonomia-asiantuntija, jonka tehtävänä olisi oman asiantuntemuksensa lisäksi osallistaa keskeisimpiä toimijaryhmiä mukaan kehitysprosesseihin. On syytä kysyä, mistä Suomessa lopulta löytyy - vai löytyykö ollenkaan - työpaikkojen tarpeisiin osaavia ergonomian ammattilaisia, jotka kykenevät jäsentämään kehittämistä sekä yksilön että organisaation ja teknologisten järjestelmien näkökulmista.

\section{Kirjoittajat}

Arto Reiman, TkT, dos., yliopistotutkija, Oulun yliopisto, Suomen

Ergonomiayhdistyksen puheenjohtaja, sähköposti: arto.reiman@oulu.fi

Teemu Suokko, TtM, työsuojelupäällikkö, MSK Group Oy, Suomen Ergonomiayhdistyksen varapuheenjohtaja, sähköposti: teemu.suokko@msk.fi

\section{Kirjallisuus}

Ahonen, G., Parvinen, L., Vainio, H., Husman, K., Ylikoski, M., Parvinen, A., Liira, J., Puputti, I. \& Parry, S. (2011) Arvopohjainen työkyvyn hallinta tehostaa työterveyshuoltoa. Suomen Lääkärilehti 11 (66), 921-926.

Alasoini, T. (2019) Tekoäly ja työn muutos sosiologisen työelämätutkimuksen uutena kohteena. Työelämän tutkimus 17 (3), 235-241.

Badri, A., Boudreau-Trudel, B. \& Souissi, A. S. (2018) Occupational health and safety in the industry 4.0 era: A cause for major concern? Safety Science 109 (Nov), 403-411. https://doi.org/10.1016/j.ssci.2018.06.012.

Burgess-Limerick, R. (2018). Participatory ergonomics: Evidence and implementation lessons. Applied Ergonomics 68 (April), 289-293. https://doi.org/10.1016/j.apergo.2017.12.009. Carayon, P. (2006) Human factors of complex socio- 
technical systems. Applied Ergonomics 37 (4), 525-535.

https://doi.org/10.1016/j.apergo.2006.04.011.

Dempsey, P. G. (2007) Effectiveness of ergonomics interventions to prevent musculoskeletal disorders: Beware of what you ask. International Journal of Industrial Ergonomics 3 (2), 169-173. https://doi.org/10.1016/j.ergon.2006.10.009.

Driessen, M. T., Proper, K. I., van Tulder, M. W., Anema, J. R., Bongers, P. M. \& van der Beek, A. J. (2010) The effectiveness of physical and organisational ergonomic interventions on low back pain and neck pain: A systematic review. Occupational \& Environmental Medicine 67 (4), 277-285. http://dx.doi.org/10.1136/oem.2009.047548.

Dul, J. \& Neumann, P. W. (2009) Ergonomics contributions to company strategies. Applied Ergonomics 40 (8), 745-752.

https://doi.org/10.1016/j.apergo.2008.07.001.

Dul, J., Bruder, R., Buckle, P., Carayon, P., Falzon, P., Marras, W.S., Wilson, J.R. \& van der Doelen, B. (2012) A strategy for human factors/ergonomics: Developing the discipline and profession. Ergonomics 55 (4), 377-395.

https://doi.org/10.1080/00140139.2012.661087.

Euroopan unionin neuvosto (2019a) Hyvinvointitalous. Neuvoston päätelmät. [online]. <URL: https://data.consilium.europa.eu/doc/document/ST-13432-2019-INIT/fi/pdf>. Luettu 14.2.2020.

Euroopan unionin neuvosto (2019b) Uusi työterveyttä ja -turvallisuutta koskeva EU:n strategiakehys: työterveyden ja -turvallisuuden tehostaminen EU:ssa. Neuvoston päätelmät. [online]. <URL:https://data.consilium.europa.eu/doc/ document/ST-14630-2019-INIT/fi/pdf >. Luettu 14.2.2020.

European Agency for Safety and Health at Work (2019) Work-related musculoskeletal disorders: revalence, costs and demographics in the EU. European Risk Observatory Report. Luxemburg: Publications Office of the European Union. https://doi:10.2802/66947.

Haims, M. C. \& Carayon, P. (1998) Theory and practice for the implementation of 'in-house', continuous improvement participatory ergonomic programs. Applied Ergonomics 29 (6), 461-472. https://doi.org/10.1016/s0003-6870(98)00012-x.

Karwowski, W. (2005) Ergonomics and human factors: The paradigms for science, engineering, design, technology and management of human- compatible systems. Ergonomics 48 (5), 436-463. https://doi.org/10.1080/00140130400029167.

Kela (2019) Pitkien sairauspoissaolojen määrä kasvoi vuonna 2018 edelleen. [online].<URL:https:// www.kela.fi/sairauspoissaolojen-tutkimus $>$. Luettu 14.2.2020.

Kleiner, B.M. (2008) Macroergonomics: Work system analysis and design. Human Factors 50 (3), 461-467. https://doi.org/10.1518/001872008x288501.

Launis, M. \& Lehtelä, J. (toim.) (2011) Ergonomia. Helsinki: Työterveyslaitos.

Rissanen, K. \& Kaseva, E. (2014) Menetetyn työpanoksen kustannukset. [online]. <URL:https:// stm.fi/menetetyn-tyopanoksen-kustannukset>. Luettu 15.2.2020.

Sosiaali- ja terveysministeriö (2019) Työympäristön ja työhyvinvoinnin linjaukset vuoteen 2030: Turvallisia ja terveellisiä työoloja sekä työkykyä kaikille. Sosiaali- ja terveysministeriön julkaisuja 3. [online]. <URL:http://julkaisut.valtioneuvosto.fi/handle/10024/161450>. Luettu 14.2.2020.

Suomen hallitusohjelma (2019) Pääministeri Sanna Marinin hallituksen ohjelma. Osallistava ja osaava Suomi - sosiaalisesti, taloudellisesti ja ekologisesti kestävä yhteiskunta. Valtioneuvoston julkaisuja 31. [online]. <URL:http://julkaisut.valtioneuvosto.fi/handle/10024/161662>. Luettu 14.2.2020.

Tapaturmavakuutuskeskus (2020a) Työtapaturmat 2009-2018. Tilastojulkaisu. [online]. <URL: https://indd.adobe.com/view/baa94c89-d2b14fa3-b10c-f421c41208a4>. Luettu 14.2.2020.

Tapaturmavakuutuskeskus (2020b) Tilastosovellus Pakki. Tapaturmavakuutuskeskus. [online]. <URL:https://tilastoportaali.vakes.fi/>. Luettu 15.2.2020.

Thatcher, A., Waterson, P., Todd, A. \& Moray, N. (2018) State of science: Ergonomics and global issues. Ergonomics 61 (2), 197-213. https://doi. org/10.1080/00140139.2017.1398845.

Vink, P., Imada, A. S. \& Zink, K. J. (2008) Defining stakeholder involvement in participatory design processes. Applied Ergonomics 39 (4), 519-526. https://doi.org/10.1016/j.apergo.2008.02.009.

Westgaard, R. H. \& Winkel, J. (2011) Occupational musculoskeletal and mental health: Significance of rationalization and opportunities to create sustainable production systems - A systematic review. Applied Ergonomics 42 (2), 261-296. https://doi.org/10.1016/j.apergo.2010.07.002. 